\title{
The Impact of Covid-19's Challenges on Education Institutional Development in MENA Region
}

\author{
Ameen Mohammed Mustafa \\ 192210009@aue.ae \\ College of Business Administration, American University in the Emirates, UAE
}

\begin{abstract}
Various regulation has been implemented in United Arab Emirates at the beginning of the novel virus covid-19, to ensure the safety for students, and studying continuity, a change has to be done. Literature review in this research paper will discuss some factors, which are the challenges that affected the development of moving from traditional education to E-learning, or distance learning. Based on that factors a survey conducted using survey monkey, the goal was to collect a minimum of 150 respondents, luckily survey collected 167 respondents, a quantitative approach followed as a method to analyze the data using Statistical Product and Service Solutions software. Using such a software will give us a clear image about the relationship between all the factors that related to the challenges of e-learning system during the pandemic. After analyzing the data, the results conclude that teacher readiness and student willingness will affect positively and significantly on institutional development as those factors strengthen the relationship, by that they will achieve a better development, and there is a strong positive relation between the internet infrastructure of the country and the educational development.
\end{abstract}

Keywords: Internet Infrastructure, teacher readiness to the change, student willingness, government regulation, institutional development

\begin{abstract}
Introduction
After the speared of the corona virus, many industries got affected negatively around the world, and one of the most important industry affected is education, it considers as big potential and future of any country, thus, the leadership of United Arab Emirates made their effort to ensure finishing of the academic year without failing, on $8^{\text {th }}$ of march they made the announcement for E-learning distance, and gave a break of four weeks to the students, as it was during the lockdown of the country, as they lockdown for safety purposes. On 22nd of March 2020, 1.2 Million students from school and university get back to the education in UAE, and that was a big step, and student's parents get more comfortable as they can see their son/daughter studying, and they can observe that. Dubai's education regulator has provided various of online platform software like Microsoft Team, and the application has facilitated a lot of things, you can upload your assignment/HomeWorks, and so on. The government of UAE understand the economic situation, so they asked school to make fee waiver, and not to consider the bus fees which was paid earlier at the beginning $g$ of the semester and refund it (Mansoor, 2020).

The factors that the research will study are internet enables learning infrastructure, as it is the key part of this e learning to have a better connection to connect virtually and attend the class, another factor is government regulation and rules that deployed to implement and sustain the education working in the country, not to forget how teacher is ready for such a change, and the willingness of student as well.
\end{abstract}

\section{Research problem}

Because of the separation of the corona virus, many things have been changing in the country in terms of education, the development change has many challenges affected the education system as whole, and finally, the education institution development as whole, which is the problem

\section{Research Questions}

- How students in UAE react to government rules and regulation, and the challenges forced on education system?

The current issue and full text archive of this journal is available at www.jraspublications.org/index.php/JRAS/issue/archive Journal of Research in Administrative Sciences (JRAS)

VIII(II), 27-34, ISSN: 2664-2433
- How teachers and students accepted such a change, and how ready and willing to study online?

\section{Research Objectives}

Investigating on how the challenges of online education affected the education system as whole, and the acceptance of students and teacher on such a grow in education institution development

\section{Literature Review Institutional Development}

Development of any industry require time and efforts, strategy to do it, and e learning, is a top precedence in United Arab Emirates, and like other, UAE, has closed university campus and classes, as a precautionary measure to protect the students in UAE, and everyone start using the online education system, which some people even think that after finding the vaccine, online learning will still be a big part of education, to develop in a proper way of course you must have a very good internet infrastructure, and in this research will study how internet effect on institutional development of education as whole, and how it is acting as a dependent variable (Tabrez, 2020). Institutional development is considered as a main factor in this study, and the related literature with other findings factors is discussed in the coming text.

\section{Government regulation}

Before talking about the challenges of the change from traditional learning to distance learning, the first part of literature review is the government regulation, in this research paper, it consider as moderator variable, as it is part and the relation to strengthen the intuitional development of education in the United Arab Emirates (Masudi,2020). As said earlier, E-learning start remoting on $22^{\text {nd }}$ of March 2020, and under the guidance of council minister and leadership of UAE, they have announced that e-learning will be continue until the end of the academic year of 2019/2020 for all high education institutes, and as said By Dr. Amna Al-dahhak, such a decision has been taken to ensure the safety of students, and the continuity of the learning to secure their future without losing the academic year. There was a training session for parents to learn about the application that their son/daughter are going to 
use, to be familiar with, and to support their children, thus, will give them the best environment for learning (Godinho, 2020). After the detailed literature review related with government regulation the moderator variable in this research, it was identified that there exists a gap of connecting this variable with institutional development. Therefore, sixth hypothesis (H6: Government Regulation will moderate significantly the relation between the internet enabled infrastructure and institutional development).

\section{Moderation}

Government regulation on this research is acting as a moderator variable, this variable from its name is working between the two variables, and the one responsible for the interaction between independent, and dependent variables, and in this research case the government regulation decision is a moderator between the internet infrastructure of the country and the education institutional development as the online education system, moreover, the moderator can increase and enhance the change or the development of the online education, and in analysis part of this research will discussed the relation and effect of the moderator variable, and how significant related to our research model.

\section{Internet Enabled Learning Infrastructure}

After talking about the government's new regulation, authority of UAE promoted with Telecommunication Regulatory authority, known as "TRA" with coordinating with Etisalat and DU, by sharing a list of applications to facilitate the E-learning system, such as, zoom, skype for business, Microsoft Teams, and blackboard. Microsoft Team is been used in American university in the emirates, where the application can show you the students who are attending, you can share your thoughts on the chatting box, you can share you screen as well with instructor and colleagues, moreover, you can use it to submit assignment, and make internal meeting with the colleagues as well (Merjen, 2020). TRA also enabled internet for families who doesn't have internet at their home, as a support for them to connect to the application and to access the successful of the online distance approach (Mansoor, 2020). After the detailed literature review related with internet enabled learning and few other variables, it was identified that there exists a gap of connecting this variable with institutional development.

Therefore, first hypothesis (H1: There is a significant relationship between Internet enabled learning infrastructure and Institutional development) for the study is proposed, the second hypothesis, $(\mathrm{H} 2$ : Internet infrastructure of the country is directly affected Teacher readiness on Online education system), third hypothesis, (H3: internet infrastructure of the country is directly affected student's willingness into Online education system).

\section{Independent Variable}

In this paper research the internet infrastructure in the country will act as an independent variable, and from its name it is independent and nothing will affect it, but this variable will affect the whole idea of the title of developing and changing into the online education, and it is the main variable that can do a change to the system of online learning, because without it, simply there is no online education.

\section{Teacher Readiness for online education}

After the pandemic of the covid-19, it must consider a very important factor in education structure which is the teachers themself, and how ready they are. Schools and University started to make a training program for teacher, and that training comprise into the training on software, and online teaching method, the training on the software is very important, showing how the software will facilitate many things (Mathew, 2020). That is noticeable in Microsoft Team, as you can raise your hand, participate, not only the software, for exam there is what called "lockdown browser" which they are using for exam, as once the browser is opened and the exam started the student has to open his/her mic and camera, however, another important thing is how teachers are ready to teach the students in such a way, because as known that every individual teacher has his/her own style in teaching, so that was another challenge (Rizvi, 2020). After the detailed literature review related with this variable which is the teacher readiness and few other affected variables, it was identified that there exists a gap of connecting this variable with institutional development. Therefore, fourth hypothesis, (H4: Teacher readiness on Online education system, has a direct \& significant impact on education institutional development), moreover, seven hypothesis also related to the teacher readiness, which is the mediator of this hypothesis, (H7: Teacher readiness on Online education system, will mediate the relationship between Internet enabled learning infrastructure and Institutional development).

\section{Students Willingness to Online Education}

The other aspect after teacher is defiantly the students themselves, of course students will face some challenges at least at the beginning until they get used to it, the main key here is how to build strategies in learning that can enhance and motivate the student as if it was the traditional education, a very good example on that is what Manipal academy doing, they are doing normal classes no doubt, same time, they are established a virtual happy hours, where students can open their mic and camera and start talking, this kind of practice will enhance and motivate the student instead of making him boring, also, they are doing fitness challenges, to challenges between one another, this will encourage them and sport will pump and energize the brain, and the student will be more willing to take a class (Zaman, 2020) Another important thing is the laboratory and how to inspire the student, remote lab technology using internet of thing is a good practice, and students can watch the experiments from zero to 100 percent, as there are camera in every angle, this practice has been done at BITS Dubai, such a practice required a good IT team and expertise especially when it comes to intern of things (Sengupta, 2020). After the detailed literature review related with this variable which is the student willingness and few other affected variables, it was identified that there exists a gap of connecting this variable with institutional development. Therefore, fifth hypothesis, (H5: Student's willingness into Online education system., has a direct \& significant impact on education institutional development, moreover, eighth hypothesis also related to the student willingness, which is the mediator of this hypothesis, (H8: Student's willingness into Online education system, will mediate the relationship between Internet enabled learning infrastructure and Institutional development).

\section{Mediation Variable}

In this research student willingness, and teacher readiness will work both as a mediator variables, to mediates between the independent and dependent variable, usually, the independent variable like in this research case the internet infrastructure will make a change in the system, and the mediators variable here student/teacher readiness and willingness will lead that change to make it happen to the dependent variable which is the development of the institutional as whole. Generally the main purpose at the analysis part is to test which variable is making more effect on the dependent variable, is it the mediator or the independent variable, at the same it is important to check the correlation to understand the relationship between them, and that is what will be tested later in the next text of this research.

\section{Research Design}

The research designed to answer the research question by using descriptive research design, assuming some hypothesis related to the main title and problem of the research, by studying the challenges that affected the education system, as earlier mentioned, data will be collected using Survey questionnaire statement related to the same factors, the questionnaire statement will be Likert scaling method type of question to understand the degree of acceptance (agree or disagree) responses, analyze it using SPSS software, using Pearson Correlation method, and regression method. Based on what has been conducted in the literature review, a research model has been created as shown in the below diagram no. 1 


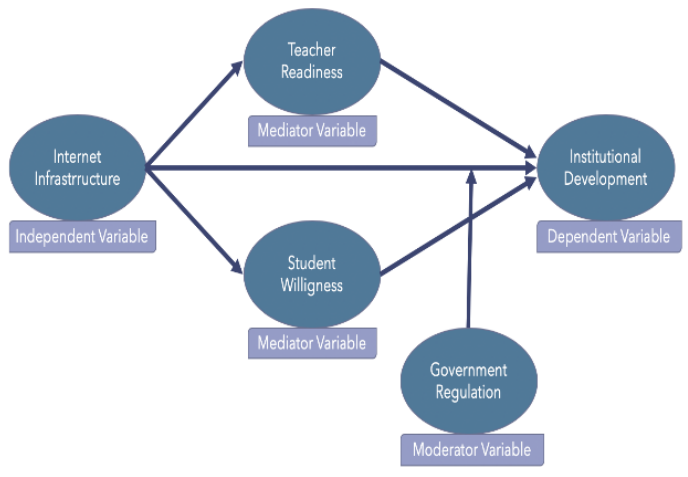

Diagram No.1: Research Mode

Table no. 1 below show the supported reference's tabulation for each variable as stated previously in the literature review.

\begin{tabular}{|l|l|}
\hline $\begin{array}{c}|c| \\
\text { E-learning Development } \\
\text { challenges during the pandemic } \\
\text { of Covid-19 }\end{array}$ & Reference Support \\
\hline $\begin{array}{l}\text { Independent Variable: Internet } \\
\text { Infrastructure }\end{array}$ & $\begin{array}{l}\text { (Mansoor, 2020), } \\
\text { (Merjen, 2020) }\end{array}$ \\
\hline $\begin{array}{l}\text { Dependent Variable: } \text { Institutional } \\
\text { Development }\end{array}$ & (Tabrez, 2020) \\
\hline $\begin{array}{l}\text { Mediator 1: Teacher Readiness } \\
\text { Mediator 2: Student willingness }\end{array}$ & $\begin{array}{l}\text { (Sengupta, 2020), } \\
\text { (Rizvi, 2020), } \\
\text { (Mathew, 2020), } \\
\text { (Zaman, 2020) }\end{array}$ \\
\hline $\begin{array}{l}\text { Moderator: Government } \\
\text { Regulation }\end{array}$ & $\begin{array}{l}\text { (Godinho, 2020), } \\
\text { (Masudi, 2020) }\end{array}$ \\
\hline
\end{tabular}

Table (1): Reference Tabulation

\section{Research Hypothesis}
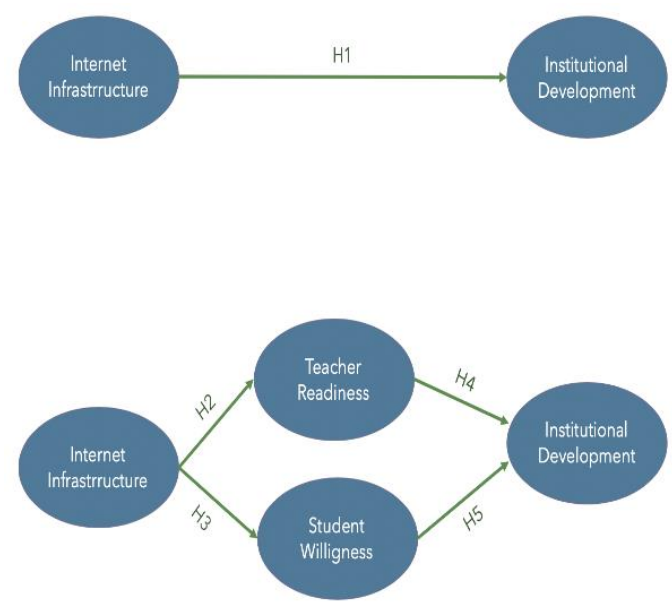

Diagram No.2 Research Hypothesis for H1, H2, H3, H4, and H5.

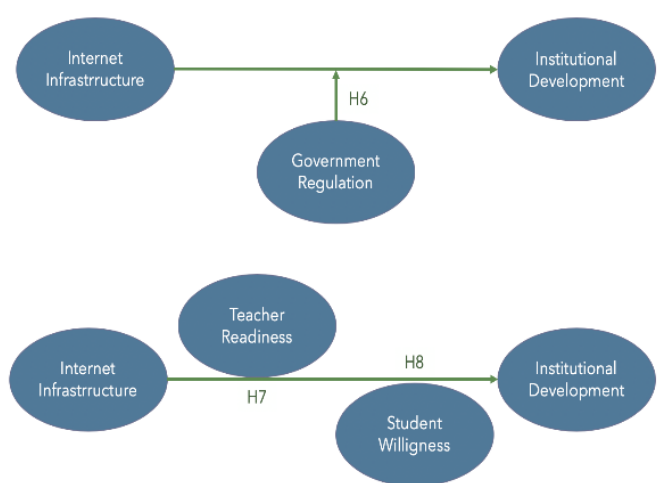

Diagram No.3 Research Hypothesis for H6, H7, and H8

\section{Research Methodology}

As discussed previously, and after conducting the hypothesis research, it is time to prepare research questionnaire statement, remember that this research is following the quantitative approach, after collecting research data, will use Statistical Product and Service Solutions "SPSS" software to test research hypothesis, correlation method will be use, and linear regression analysis as well, also will use Andrew F. Hayes process in analyzing the effect of moderation and mediation variables, to understand how they impacted research model as whole, and to understand the variation percentage for each variable in research's dependent variable, which is "Education institutional development". Research questionnaire statements are mentioned in appendix A.

\section{Research Questionnaire Statements}

\section{About research questionnaire and its variables}

The questionnaire statements are conducted and prepared to investigate what is the audience experienced on online education development change in the country, and how they are reflecting to the challenges of the change.

\begin{tabular}{|c|l|c|}
\hline No. & \multicolumn{1}{|c|}{ Variable } & \multicolumn{1}{|c|}{ Items } \\
\hline $\mathbf{1}$ & $\begin{array}{l}\text { Internet enabled learning } \\
\text { infrastructure }\end{array}$ & $\begin{array}{c}\text { 3 Questions } \\
\text { (Q05 - Q07) }\end{array}$ \\
\hline $\mathbf{2}$ & Government regulations & $\begin{array}{c}\text { 3 Questions } \\
\text { (Q08 - Q10) }\end{array}$ \\
\hline $\mathbf{3}$ & $\begin{array}{l}\text { Teacher Readiness to the } \\
\text { change }\end{array}$ & $\begin{array}{c}\text { 3 Questions } \\
\text { (Q11 - Q13) }\end{array}$ \\
\hline $\mathbf{4}$ & $\begin{array}{l}\text { Student willingness to } \\
\text { change }\end{array}$ & $\begin{array}{c}\text { 3 Questions } \\
\text { (Q14 - Q16) }\end{array}$ \\
\hline $\mathbf{5}$ & Institutional development & $\begin{array}{c}\text { 3 Questions } \\
\text { (Q14 - Q15) }\end{array}$ \\
\hline
\end{tabular}

Table (2): Research Variables and questions coverage

Survey has been conducted for only the students who are studying in United Arab Emirates, and it was conducted using survey monkey website, there was a demographic questions from question one to question four, then the other questions are prepared based on the variables that discussed in the literature review and in the research model previously, and table no. 2 above is showing the coverage of each variable and where it was covered in which questioned, noticing that each variable has three questions that have been asked in order to make the variable more rich and reliable at the analysis part.

\section{Data Analysis}

Data has been collected using survey monkey website, collected 170 respondents, 3 candidates has a missing data, so it was omitted, so total of 167 respondents will be use in this research analysis 


\subsection{Frequency test}

At the beginning of the test, we must check if we have any outliers/missing data, just to make sure, will use the demographic variable to do that, moreover, will see who are our candidates, what is their gender, what is their age range, what is their educational level, how many courses they are taken every week.

\begin{tabular}{llll|l|l}
\multicolumn{2}{l}{ Statistics } & \multicolumn{2}{l}{} & \multicolumn{2}{l}{} \\
& Gender & Age & $\begin{array}{l}\text { Educational } \\
\text { Level }\end{array}$ & $\begin{array}{l}\text { Class } \\
\text { Attending }\end{array}$ \\
\hline \multirow{2}{*}{$\mathrm{N}$} & Valid & 167 & 167 & 167 & 167 \\
\cline { 2 - 6 } & Missing & 0 & 0 & 0 & 0 \\
\hline Mean & 1.6108 & 1.3653 & 1.3892 & 1.9042 \\
\hline Std. Deviation & .48904 & .48295 & .48904 & .88654 \\
\hline
\end{tabular}

Table (3): Frequency Table Statistics

As it is showing from table no. 3 above, frequency table statistics, there are no missing data, this is very important step, because sometimes we can't see if there is a missing data by eye, a double check is very necessary to do, zero missing data, mean we can go through.

\begin{tabular}{ccc|c|c|c} 
& \multicolumn{2}{c}{ Gender } & & \\
& & Frequency & Percent & $\begin{array}{c}\text { Valid } \\
\text { Percent }\end{array}$ & $\begin{array}{c}\text { Cumulative } \\
\text { Percent }\end{array}$ \\
\hline \multirow{3}{*}{ Valid } & Male & 65 & 38.9 & 38.9 & 38.9 \\
\cline { 2 - 6 } & Female & 102 & 61.1 & 61.1 & 100.0 \\
\cline { 2 - 6 } & Total & 167 & 100.0 & 100.0 & \\
\hline
\end{tabular}

Table (4) Gender frequency statistics

In table no. 4 above that most of the candidates of the survey are female gender, $61.1 \%$ are female, and $38.9 \%$ are male candidates, and most of them $63.5 \%$ have age between eighteen to twenty eight years old, and the rest $36.5 \%$ have an age between twenty nine to fifty years old, as shown in table no. 5 below.

\begin{tabular}{ccc|c|c|c} 
& \multicolumn{5}{c}{ Age } \\
& Frequency & Percent & $\begin{array}{c}\text { Valid } \\
\text { Percent }\end{array}$ & $\begin{array}{c}\text { Cumulative } \\
\text { Percent }\end{array}$ \\
\hline \multirow{3}{*}{ Valid } & $\begin{array}{c}18-28 \\
\text { years old }\end{array}$ & 106 & 63.5 & 63.5 & 63.5 \\
\cline { 2 - 6 } & $\begin{array}{c}29-50 \\
\text { years old }\end{array}$ & 61 & 36.5 & 36.5 & 100.0 \\
\cline { 2 - 6 } & Total & 167 & 100.0 & 100.0 & \\
\hline
\end{tabular}

Table (5) Age frequency statistics

Most of the candidates $61.1 \%$ are bachelor's degree students, only $38.9 \%$ of them are postgraduate students, and table no. 6 below are explaining that.

\begin{tabular}{|c|c|c|c|c|c|}
\hline \multicolumn{6}{|c|}{ Educational Level } \\
\hline & & Frequency & Percent & $\begin{array}{c}\text { Valid } \\
\text { Percent }\end{array}$ & $\begin{array}{c}\text { Cumulative } \\
\text { Percent }\end{array}$ \\
\hline \multirow{3}{*}{ Valid } & $\begin{array}{c}\text { Bachelor's } \\
\text { Degree Student }\end{array}$ & 102 & 61.1 & 61.1 & 61.1 \\
\hline & $\begin{array}{c}\text { Postgraduate } \\
\text { Student }\end{array}$ & 65 & 38.9 & 38.9 & 100.0 \\
\hline & Total & 167 & 100.0 & 100.0 & \\
\hline
\end{tabular}

\section{Table (6) educational level frequency statistics}

And most of the candidates attend one to two classes per week, it is very a smaller number of classes, and that is clear as the survey was taken during the summer semester, where it has less classes compare to the Fall semester, figure no. 1 below showing the pie chart of the number of class that has been taken by the candidates, and table no. 7 explaining that by percentage, where $42.5 \%$ of students who are taking two classes per week, $37.1 \%$ of students who are taking only one class per week, $13.2 \%$ of student who are taking three classes per week, and only $7.2 \%$ of students are taking more than three classes per weeks.
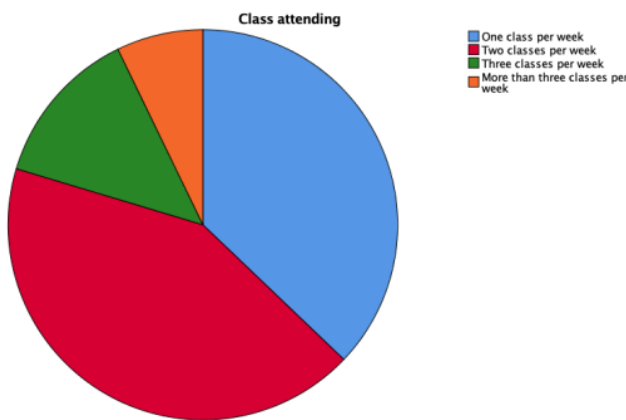

Figure (1): Pie Chart for the candidates who are taking online classes per week

\section{Class attending}

\begin{tabular}{|c|c|c|c|c|c|}
\hline \multicolumn{6}{|c|}{1.1} \\
\hline & & Frequency & Percent & $\begin{array}{l}\text { Valid } \\
\text { Percent }\end{array}$ & $\begin{array}{l}\text { Cumulative } \\
\text { Percent }\end{array}$ \\
\hline \multirow{5}{*}{ Valid } & $\begin{array}{l}\text { One class } \\
\text { per week }\end{array}$ & 62 & 37.1 & 37.1 & 37.1 \\
\hline & $\begin{array}{l}\text { Two classes } \\
\text { per week }\end{array}$ & 71 & 42.5 & 42.5 & 79.6 \\
\hline & $\begin{array}{l}\text { Three } \\
\text { classes per } \\
\text { week }\end{array}$ & 22 & 13.2 & 13.2 & 92.8 \\
\hline & $\begin{array}{l}\text { More than } \\
\text { three } \\
\text { classes per } \\
\text { week }\end{array}$ & 12 & 7.2 & 7.2 & 100.0 \\
\hline & Total & 167 & 100.0 & 100.0 & \\
\hline
\end{tabular}

Table (7): Candidates who are taking online classes per week statistics

\section{Normality Test}

The data usually skewed or kurtotic, and this test will show how our collected data are normally distributed, the skewness of the data should getting close to the zero, which mean the collected data are perfectly normally distributed, if it was getting close to the one it mean the collected data are skewed to the left or to the right, but it should not be more than 1 , for an example will do a test on the three variable if internet enable infrastructure, using SPSS software > analyze - descriptive statistics - explore.

As we can see in table no. 8 below skewness and kurtosis for Internet enabled learning infrastructure (IELI1, IELI2, IELI3) are below the absolute value of one , but it is not getting to the zero, so there is some skewness, as will be seen in figure no. 2 below for IELI1. 
Normality Test - Descriptive

\begin{tabular}{|c|c|c|c|c|}
\hline \multicolumn{3}{|l|}{ 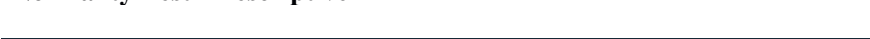 } & \multirow{2}{*}{$\frac{\text { Statistic }}{3.7186}$} & \multirow{2}{*}{$\frac{\text { Std. Error }}{.08863}$} \\
\hline \multirow{13}{*}{$\begin{array}{l}\text { Internet enabled learning } \\
\text { infrastructure } 1\end{array}$} & Mean & & & \\
\hline & \multirow{2}{*}{$\begin{array}{l}95 \% \text { Confidence } \\
\text { Interval for Mean }\end{array}$} & $\begin{array}{l}\text { Lower } \\
\text { Bound }\end{array}$ & 3.5436 & \\
\hline & & Upper Bound & 3.8936 & \\
\hline & \multicolumn{2}{|c|}{ 5\% Trimmed Mean } & 3.7961 & \\
\hline & \multicolumn{2}{|l|}{ Median } & 4.0000 & \\
\hline & \multicolumn{2}{|l|}{ Variance } & 1.312 & \\
\hline & \multicolumn{2}{|l|}{ Std. Deviation } & 1.14537 & \\
\hline & \multicolumn{2}{|l|}{ Minimum } & 1.00 & \\
\hline & \multicolumn{2}{|l|}{ Maximum } & 5.00 & \\
\hline & \multicolumn{2}{|l|}{ Range } & 4.00 & \\
\hline & \multicolumn{2}{|l|}{ Interquartile Range } & 2.00 & \\
\hline & \multicolumn{2}{|l|}{ Skewness } & -.549 & .188 \\
\hline & \multicolumn{2}{|l|}{ Kurtosis } & -.449 & .374 \\
\hline \multirow{13}{*}{$\begin{array}{l}\text { Internet enabled learning } \\
\text { infrastructure } 2\end{array}$} & Mean & & 3.6766 & .08290 \\
\hline & \multirow{2}{*}{$\begin{array}{l}95 \% \text { Confidence } \\
\text { Interval for Mean }\end{array}$} & $\begin{array}{l}\text { Lower } \\
\text { Bound }\end{array}$ & 3.5130 & \\
\hline & & Upper Bound & 3.8403 & \\
\hline & \multicolumn{2}{|c|}{ 5\% Trimmed Mean } & 3.7495 & \\
\hline & \multicolumn{2}{|l|}{ Median } & 4.0000 & \\
\hline & \multicolumn{2}{|l|}{ Variance } & 1.148 & \\
\hline & \multicolumn{2}{|l|}{ Std. Deviation } & 1.07137 & \\
\hline & \multicolumn{2}{|l|}{ Minimum } & 1.00 & \\
\hline & \multicolumn{2}{|l|}{ Maximum } & 5.00 & \\
\hline & \multicolumn{2}{|l|}{ Range } & 4.00 & \\
\hline & \multicolumn{2}{|l|}{ Interquartile Range } & 2.00 & \\
\hline & \multicolumn{2}{|l|}{ Skewness } & -.573 & .188 \\
\hline & \multicolumn{2}{|l|}{ Kurtosis } & -.053 & .374 \\
\hline & Mean & & 3.9760 & .07402 \\
\hline & 95\% Confidence & $\begin{array}{l}\text { Lower } \\
\text { Bound }\end{array}$ & 3.8299 & \\
\hline & Interval for Mean & Upper Bound & 4.1222 & \\
\hline & $5 \%$ Trimmed Mean & & 4.0556 & \\
\hline & Median & & 4.0000 & \\
\hline Internet enabled learning & Variance & & .915 & \\
\hline infrastructure 3 & Std. Deviation & & .95660 & \\
\hline & Minimum & & 1.00 & \\
\hline & Maximum & & 5.00 & \\
\hline & Range & & 4.00 & \\
\hline & Interquartile Range & & 2.00 & \\
\hline & Skewness & & -.913 & .188 \\
\hline & Kurtosis & & .756 & .374 \\
\hline
\end{tabular}

Table (8): Normality Test for IELI variables

We can test the normality test by usin Z-value, from the following formula $\frac{\text { Skewness or kurtosis Statistic value }}{\text { Std Error value }}$, and it should be between -1.96 to

+1.96 , example on that for variable IELI1 $=\frac{\text { skewness }-0.449}{\text { std error } 0.374}=-1.2$ it is acceptable, and so on.

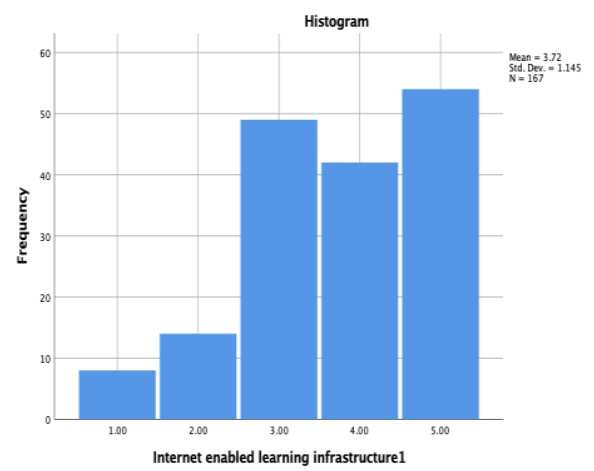

Figure (2): Normal distribution histogram for IELI1

\section{Reliability Test}

After the normality test and checking the distribution of the variables, $t$ is very essential to test the internal consistency of the variables and how reliable to each other, and here it is important to test Cronbach Alpha of variables and it should be more than 0.7 , if it is getting close to 1 it mean that variables any type of question make the internal consistency of the questions reliable to each other, and that is based on the audience reflection to the questionnaire statements, and for any test has reliability less than 0.7 , will be omitted from the research, getting 0.5 or 0.4 is not acceptable.

From analyze - scale - reliability test

Table no. 9 below, clearly showing the excellent consistency

between all variables, all above 0.7 that mean they are all reliable 


\begin{tabular}{|c|c|c|c|c|c|}
\hline & $\begin{array}{l}\text { Scale Mean if Item } \\
\text { Deleted } \\
\end{array}$ & $\begin{array}{c}\text { Scale Variance if } \\
\text { Item Deleted }\end{array}$ & $\begin{array}{l}\text { Corrected Item- } \\
\text { Total Correlation }\end{array}$ & $\begin{array}{c}\text { Squared Multiple } \\
\text { Correlation }\end{array}$ & $\begin{array}{l}\text { Cronbach's Alpha } \\
\text { if Item Deleted }\end{array}$ \\
\hline $\begin{array}{l}\text { Internet enabled learning } \\
\text { infrastructure } 1\end{array}$ & 69.0871 & 100.214 & .563 & .857 & .867 \\
\hline $\begin{array}{l}\text { Internet enabled learning } \\
\text { infrastructure } 2\end{array}$ & 69.3915 & 99.532 & .532 & .812 & .868 \\
\hline $\begin{array}{l}\text { Internet enabled learning } \\
\text { infrastructure } 3\end{array}$ & 69.4138 & 104.026 & .323 & .803 & .878 \\
\hline Government regulations1 & 69.6303 & 94.994 & .738 & .844 & .862 \\
\hline Government regulations 2 & 69.0651 & 103.440 & .510 & .672 & .873 \\
\hline Government regulations 3 & 69.0651 & 105.796 & .394 & .527 & .873 \\
\hline Teacher Readiness to the change 1 & 69.8911 & 107.077 & .218 & .422 & .881 \\
\hline Teacher Readiness to the change 2 & 69.5010 & 101.989 & .448 & .746 & .873 \\
\hline Teacher Readiness to the change 3 & 69.5100 & 101.811 & .511 & .637 & .870 \\
\hline Student willingness to change1 & 69.3042 & 103.861 & .419 & .812 & .872 \\
\hline Student willingness to change 2 & 69.2172 & 101.818 & .558 & .880 & .868 \\
\hline Student willingness to change 3 & 69.3912 & 105.310 & .317 & .365 & .877 \\
\hline Institutional development 1 & 70.0871 & 101.770 & .387 & .745 & .871 \\
\hline Institutional development2 & 69.8479 & 99.732 & .562 & .778 & .865 \\
\hline Institutional development 3 & 69.1523 & 102.354 & .437 & .908 & .875 \\
\hline
\end{tabular}

\section{Table (9): Reliability test for all variables}

\section{Data Summarization \& Reduction}

After all required test, final step to do before doing testing the hypothesis, is doing a summarization to the variables, this research has 5 variables, each variable has three question, will take the summary by taking the avg of each variable, to do so, transform- compute variable.

\section{Testing Hypothesis \& research Results}

Hypothesis 1 As mentioned earlier, about research hypothesis, now it is time to test one by one, the first test is H1, there is a significant relationship between IELI and ID, in another word, the relation between independent and dependent variables.

Table no. 10 below showing Pearson correlation method between the two variables, and it is significant at 0.01 , it is less than 0.01 , so it is significant, and we accept the hypothesis, and that is

\section{Coefficients $^{\mathrm{a}}$}

\begin{tabular}{|c|c|c|c|c|c|c|}
\hline \multirow[b]{2}{*}{ Model } & & \multicolumn{2}{|c|}{ Unstandardized Coefficients } & \multirow{2}{*}{$\begin{array}{c}\text { Standardized Coefficients } \\
\text { Beta }\end{array}$} & \multirow[b]{2}{*}{$t$} & \multirow[b]{2}{*}{ Sig. } \\
\hline & & $\mathrm{B}$ & Std. Error & & & \\
\hline 1 & (Constant) & 3.535 & .250 & & 14.117 & .000 \\
\hline & IELInew & .091 & .065 & .108 & 1.397 & .164 \\
\hline
\end{tabular}

As we can see from table no.11 above, there is no significant relationship between internet infrastructure and Teacher readiness into change even beta has a very small variation in IELI, so we reject this hypothesis. obvious of course there is a relationship between internet and development into online education system.

\section{Correlations}

\begin{tabular}{llr|r} 
& & IELInew & \multicolumn{1}{c}{ IDnew } \\
\hline \multirow{3}{*}{ IELInew } & Pearson Correlation & 1 & .067 \\
\cline { 2 - 4 } & Sig. (2-tailed) & & .000 \\
\cline { 2 - 4 } IDnew & $\mathrm{N}$ & 167 & 167 \\
\cline { 2 - 4 } & Pearson Correlation & .067 & 1 \\
\cline { 2 - 4 } & Sig. (2-tailed) & .000 & \\
\cline { 2 - 4 } & $\mathrm{N}$ & 167 & 167 \\
\hline
\end{tabular}

Table (10): Correlation between IELI and ID

Hypothesis 2, the second test is $\mathbf{H 2}$, is stated that IELI will directly affect TRC, in this case will do regression analysis to understand.

Coefficients $^{\mathrm{a}}$

Hypothesis 3, third hypothesis H3, stated that IELI will directly affect SWC, in this case will also do regression analysis to understand.

Unstandardized Coefficients Standardized Coefficients

\begin{tabular}{|c|c|c|c|c|c|c|}
\hline \multirow[b]{2}{*}{ Model } & & \multicolumn{2}{|r|}{ zed Coemincients } & \multirow{2}{*}{$\begin{array}{l}\text { Standardized Coemicients } \\
\text { Beta }\end{array}$} & \multirow[b]{2}{*}{$\mathrm{t}$} & \multirow[b]{2}{*}{ Sig. } \\
\hline & & B & Std. Error & & & \\
\hline 1 & (Constant) & 3.354 & .251 & & 13.385 & .000 \\
\hline & IELInew & .157 & .065 & .185 & 2.412 & .01 \\
\hline
\end{tabular}

a. Dependent Variable: SWCnew

Table (12): Coefficients table predictor variables IELI and dependent variable SWCnew

In this hypothesis, and shown in table no.12 above, internet is independent variable, and SWCnew act as dependent variable, after doing linear regression analysis, we find out that relationship is significant, and there is $15.7 \%$ changes in IELI will affect SWCnew, the other percentage is affected by other factors, in this case we can accept the hypothesis

Hypothesis 4, fourth hypothesis $\mathrm{H4}$, stated that TRC will directly has significant impact on ID, in this case will also use linear regression analysis to test the hypothesis. In this test, TRCnew will work as independent variable, and IDnew like always it is the dependent variable.

Coefficients ${ }^{\mathrm{a}}$

\begin{tabular}{l|l} 
Unstandardized Coefficients & Standardized Coefficients
\end{tabular}

\begin{tabular}{llr|r|rrr|r} 
Model & & \multicolumn{2}{c}{ B } & Std. Error & Beta & t & Sig. \\
\hline \multirow{2}{*}{1} & (Constant) & 2.982 & .291 & & 10.237 & .000 \\
\cline { 2 - 8 } & TRCnew & .239 & .074 & .244 & 3.226 & .002 \\
\hline
\end{tabular}

a. Dependent Variable: IDnew

Table (13): Coefficients table predictor variables TRCnew and dependent variable IDnew 
As showing in table no.13 above, we accept the hypothesis because of its positive significant impact, the variation in teacher readiness of (Beta) $23.9 \%$ will has an impact on the institutional development of online education.

Hypothesis 5, fifth hypothesis H5, is almost similar to the fourth hypothesis, and its stated that SWC will directly has significant

\section{Coefficients $^{\mathrm{a}}$}

\begin{tabular}{|c|c|c|c|c|c|c|}
\hline \multirow[b]{2}{*}{ Model } & & \multicolumn{2}{|c|}{ Unstandardized Coefficients } & \multirow{2}{*}{$\begin{array}{c}\text { Standardized Coefficients } \\
\text { Beta }\end{array}$} & \multirow[b]{2}{*}{$\mathrm{t}$} & \multirow[b]{2}{*}{ Sig. } \\
\hline & & $\mathrm{B}$ & Std. Error & & & \\
\hline \multirow[t]{2}{*}{1} & (Constant) & 2.912 & .292 & & 9.989 & .000 \\
\hline & SWCnew & .253 & .073 & .260 & 3.463 & .001 \\
\hline
\end{tabular}

Dependent Variable: IDnew

Table (14): Coefficients table predictor variables SWCnew and dependent variable IDnew

Again, we accept the hypothesis, because of its positive significant impact, the variation in teacher readiness of (Beta) $25.3 \%$ will has an impact on the institutional development of online education.

Hypothesis 6 , sixth hypothesis, H6 is discussed how the moderator which is the government regulation, it has relationship between the independent IELInew and dependent variable IDnew, but obviously and as seen in below matrix no.1, the relationship is not significant, as $\mathrm{p}$ value more than 0.05 , but there is a $42.83 \%$ variation in this variable that explain in the dependent variable.

Model Summary

$\begin{array}{ccccccc}\mathrm{R} & \mathrm{R}-\mathrm{sq} & \mathrm{MSE} & \mathrm{F} & \mathrm{df} 1 & \mathrm{df} 2 & \mathrm{p} \\ .1745 & .0305 & .3403 & 1.7069 & 3.0000 & 163.0000 \\ .1676 & & & & & & \end{array}$

Model

\begin{tabular}{lrrrrrrl}
\multicolumn{2}{c}{ coeff } & $\mathrm{se}$ & $\mathrm{t}$ & $\mathrm{p}$ & LLCI & ULCI \\
constant & 2.0877 & 1.6569 & 1.2600 & .2095 & -2.2307 \\
6.4061 & & & & & & \\
IELInew & .3202 & .4296 & .7453 & .4571 & -.7995 & \\
1.4398 & & & & & & \\
GRnew & .4283 & .4185 & 1.0234 & .3076 & -.6624 & \\
1.5190 & & & & & & \\
Int_1 & -.0727 & .1076 & -.6760 & .5000 & -.3530 & .2076
\end{tabular}
moderator variable

Hypothesis 7, seventh hypothesis, H7, stated that TRC can lead the change of IELI and will affect it in a way to strengthen or weaken the dependent variable IDnew

\begin{tabular}{|c|c|c|c|c|c|}
\hline \multicolumn{6}{|c|}{ Model Summary } \\
\hline \multicolumn{2}{|c|}{ R R-sq } & MSE & $\mathrm{F}$ & df1 & df 2 \\
\hline .2469 & .0610 & .3276 & 5.3255 & 2.0000 & 164.0000 \\
\hline \multicolumn{6}{|l|}{.0057} \\
\hline \multicolumn{6}{|l|}{ Model } \\
\hline & eff & se & $\mathrm{p}$ & LLCI & ULCI \\
\hline $\begin{array}{l}\text { constant } \\
3.8023\end{array}$ & 2.8704 & .3576 & 8.0271 & .0000 & 1.9385 \\
\hline $\begin{array}{l}\text { IELInew } \\
.1974\end{array}$ & .0338 & .0628 & .5381 & .5913 & -.1298 \\
\hline
\end{tabular}
.4301 as a mediator variable so we accept the hypothesis. as a mediator variable
Matrix (1): matrix between IELI and IDnew, and GR as a

$\begin{array}{llllll}\text { TRCnew } & .2351 & .0748 & 3.1419 & .0020 & 0401\end{array}$

Matrix (2): matrix between IELI and IDnew, and TRCnew

As it is showing in the above matrix no. 2 it is clearly showing the IELInew is not significant in this equation, but TRCnew is still working as a mediator and it is significant, which is less than 0.05 , and the coefficient is $23.51 \%$, means the percentage variation in TRCnew can make a changes in the institutional development,

Final Hypothesis in this research is $\mathbf{H 8}$, stated that SWC can lead the change of IELI and will affect it in a way to strengthen or weaken the dependent variable IDnew, ame as in hypothesis no.7, will use Andrew F. Hayes Process from regression , model 4.

\begin{tabular}{|c|c|c|c|c|c|}
\hline \multicolumn{2}{|c|}{ Model Summary } & \multirow[b]{2}{*}{ MSE } & \multirow[b]{2}{*}{$F$} & \multirow[b]{2}{*}{ df1 } & \\
\hline $\mathrm{R}$ & R-sq & & & & df 2 \\
\hline .2610 & .0681 & .3251 & 5.9930 & 2.0000 & 164.0000 \\
\hline \multicolumn{6}{|l|}{.0031} \\
\hline \multicolumn{6}{|l|}{ Model } \\
\hline & eff & $\mathrm{t}$ & $\mathrm{p}$ & LLCI & ULCI \\
\hline $\begin{array}{l}\text { constant } \\
3.7676\end{array}$ & 2.8653 & .3462 & 8.2754 & .0000 & 1.9629 \\
\hline $\begin{array}{l}\text { IELInew } \\
.1809\end{array}$ & .0160 & .0633 & .2533 & .8003 & -.1488 \\
\hline $\begin{array}{l}\text { SWCnew } \\
.4434\end{array}$ & .2493 & .0745 & 3.3467 & .0010 & .0552 \\
\hline
\end{tabular}

Matrix (3): matrix between IELI and IDnew, and SWCnew

Same like in hypothesis no.7, matrix no. 3 is showing that the mediator is significant in this hypothesis, and is doing a changes by $24.93 \%$ means the percentage variation in SWCnew can make a changes in the institutional development, so we accept the hypothesis, and below table is a summary for all the hypothesis

\begin{tabular}{|c|l|l|}
\hline No. & \multicolumn{1}{|c|}{ Hypothesis } & \multicolumn{1}{|c|}{ Result after testing } \\
\hline 1 & $\begin{array}{l}\text { There is a significant relationship between Internet enabled learning infrastructure } \\
\text { and Institutional development. }\end{array}$ & $\begin{array}{l}\text { Accept Hypothesis, } \\
\text { Significant relationship }\end{array}$ \\
\hline 2 & $\begin{array}{l}\text { Internet infrastructure of the country is directly affected Teacher readiness on } \\
\text { Online education system. }\end{array}$ & $\begin{array}{l}\text { Reject hypothesis, } \\
\text { as it is not significant }\end{array}$ \\
\hline 3 & $\begin{array}{l}\text { Internet infrastructure of the country is directly affected student's willingness into } \\
\text { Online education system. }\end{array}$ & $\begin{array}{l}\text { Accept Hypothesis, } \\
\text { Significant positive relation. }\end{array}$ \\
\hline 4 & $\begin{array}{l}\text { Teacher readiness on Online education system, has a direct \& significant impact on } \\
\text { education institutional development. }\end{array}$ & $\begin{array}{l}\text { Accept Hypothesis, } \\
\text { Significant positive relation. }\end{array}$ \\
\hline 5 & $\begin{array}{l}\text { Student's willingness into Online education system has a direct \& significant } \\
\text { impact on education institutional development. }\end{array}$ & $\begin{array}{l}\text { Accept Hypothesis, } \\
\text { Significant positive relation. }\end{array}$ \\
\hline 6 & $\begin{array}{l}\text { Government Regulation will moderate significantly the relation between the } \\
\text { internet enabled infrastructure and institutional development. }\end{array}$ & $\begin{array}{l}\text { Partially accepted, it is not significant but there } \\
\text { is a variation. }\end{array}$ \\
\hline 7 & $\begin{array}{l}\text { Teacher readiness on Online education system, will mediate the relationship } \\
\text { between Internet enabled learning infrastructure and Institutional development. }\end{array}$ & $\begin{array}{l}\text { Accept Hypothesis, } \\
\text { Significant positive variation changed. }\end{array}$ \\
\hline 8 & $\begin{array}{l}\text { Student's willingness into Online education system, will mediate the relationship } \\
\text { between Internet enabled learning infrastructure and Institutional development. }\end{array}$ & $\begin{array}{l}\text { Accept Hypothesis, } \\
\text { Significant positive variation changed. }\end{array}$ \\
\hline
\end{tabular}




\section{Conclusion}

This research has discussed the change and developing from traditional education to online education, and these changes was because of the novel virus that attacked the global, so there was no other decision to take better than this, to warrant student's future, and there was eight hypothesis, and it was noticeable that government regulation is affected by a high variation percentage, but it was not significant in this case because it is working as a moderator between internet infrastructure and institutional development, however, the mediators were working significantly in this research and they positioned correctly, teacher readiness to the changes, and student willing to open their system and connect with their teacher to study was significant in a way to grow in the institutional development and made a very good variation, teacher readiness has a variation of $23.9 \%$ in the institutional development, and student willingness to change has $25.3 \%$ in the institutional development. Also, it was noticeable that the internet infrastructure correlate significantly with development growth of online education, and it will be a good approach if they enhance the internet even better, deploying 5G network technology could make a big difference especially for schools and university who are implementing internet of things system.

\section{Recommendations}

it is very important for any industry to understand its resources and main variables, moreover, they should understand the mediator they have at the organization/company, because it is the relation and can strengthen the goal of a certain business. Another important aspect is the moderator of the organization, very important to find the moderator in our company and use it in a way to satisfy people and achieve better, because it is responsible for the interaction between independent and dependent variable (the objective of every business).

\section{Further Research and Limitation}

The research used some variables, that can reduced the challenges of covid-19, which are the internet infrastructure, teacher readiness, students willingness, another variable could be used in the future, which it could be by implementing the software, and it could be possible to use virtual reality $3 \mathrm{D}$, in a way that make you feel more satisfy, and seeing your teacher and students, like if they were real, such a technology can be used if the virus stay for a long period, hybrid class is also another approach, as student can attend some classes online, and another one at university, of course with following the best precautionary measure, and social distance practices, another aspect here is the limitation of the research, as the time is very limited it could have collected more respondents to give a better explanation in the analysis part, moreover, it is still new to the audience, and they need time to cope with the idea of the change, because any change in any industry required time, to manage and to achieve a better performance, and that is the main goal.

\section{References}

i. Mansoor, Z (2020, April 13), How is Covid-19 changing the UAE's educational landscape? Retrieved from https://gulfbusiness.com/how-is-covid-19-changing-theuaes-educational-landscape/

ii. Godinho, V (2020, March 30), All UAE schools, universities to extend e-learning programmes until June. Retrieved from https://gulfbusiness.com/uae-schools-universities-extend-elearning-programmes-june/

iii. Rizvi, A (2020, March 21), Coronavirus: UAE teachers ready for distance learning but worry about connectivity. Retrieved from https://www.thenational.ae/uae/education/coronavirusuae-teachers-ready-for-distance-learning-but-worry-aboutconnectivity-1.995142

iv. Sengupta, C (2020, April 27). How UAE universities are navigating the challenges of e-learning. Retrieved from https://gulfnews.com/uae/education/how-uae-universities-arenavigating-the-challenges-of-e-learning-1.1588074560421

v. Tabrez, h (2020 August 20), E-learning at UAE universities what are your options? Retrieved from https://gulfnews.com/living-in-uae/education/e-learning-atuae-universities--what-are-your-options-1.1597072447874

vi. Zaman, S (2020, February 1). Coronavirus: UAE education regulator urges parents to keep sick children at home.
Retrieved from

https://gulfnews.com/uae/education/coronavirus-uaeeducation-regulator-urges-parents-to-keep-sick-children-athome-1.1580526726385

vii. Masudi, F (2020, April 14). Coronavirus: Thousands of UAE parents apply for relief on school fees at GEMS. Retrieved from https://gulfnews.com/uae/education/coronavirusthousands-of-uae-parents-apply-for-relief-on-school-fees-atgems-1.70970324

viii. Mejren, R (2020, July 21), UAE students create online educational initiative. $\quad$ Retrieved from https://gulfnews.com/uae/uae-students-create-onlineeducational-initiative-1.72713737

ix. Mathew, P (2020, June 29). Blended learning is the way forward for UAE universities. Retrieved from https://gulfnews.com/uae/education/blended-learning-is-theway-forward-for-uae-universities-1.1593282631641 